Egyptian J. of Nutrition Vol. XXXV No. 1 (2020)

\title{
Protective Effects of Some Juices on Toxicity of Indomethacin in Experimental Rats
}

\author{
Amira L. Abd Allah \\ Nutrition and Food Science Dept., Faculty of Home Economics, \\ Al- Azhar University
}

\begin{abstract}
This study was conducted to acquaintance the effectiveness of fresh juices (kiwi and avocado) against indomethacin toxicity in experimental rats. Thirty-six male albino rats $(185 \pm 10 \mathrm{~g})$ divided into six groups, one kept as a control (-ve) group (6 rats), while other groups 30 rats were treated orally of indomethacin $(25 \mathrm{mg} / \mathrm{kg} \mathrm{b.Wt}$.) once daily for twenty-one (21) days. One group was kept as (+ve) control group, while others given administration of kiwi juice and avocado juice (10 and $20 \mathrm{ml} / \mathrm{kg}$ ) by orally for 21 days plus Indo. At the end of the experiment, feed intake (FI), body weight gain (BWG $\%)$ and feed efficiency ratio (EFR) were calculated. Aspartate aminotransferase (AST), alanine aminotransferase (ALT),creatinine and urea were determined in serum. Red blood cell and white blood cells count were measured. Hemoglobin and hematocrit (HCT) concentration was estimated. Also, histopathological changes for liver were examined. The biochemical and histopathological analysis proved the toxic effects of indomethacin on kidney and liver. The obtained results concluded that using tested juices improved previous mentioned parameters. The best results found by using high doses of each juice. According to the results, tested juices could be used for protection from toxicity caused by indomethacin.
\end{abstract}




\section{Amira L. Abd Allah}

\section{Introduction}

Indomethacin is a methylated indole acetic acid derivative NSAIDs and commonly used in clinical therapy as anti-inflammatory, analgesic and anti-pyretic drugs (Andrade-Dávila et al., 2015). Its extensive utility is arisen from the rapid absorption, rapid and efficient crossing blood brain barrier (Perron et al., 2013). Despite of its common use, it has adverse effects including gastrointestinal, liver and kidney toxicities (Koc et al., 2019). Non-steroidal antiinflammatory drug (NSAID) such as indomethacin (INDO) is used as analgesics and anti-inflammatory agents but has toxic side effects. INDO causes deficiency in all blood cell types and has a dangerous effect on liver (Abatan et al., 2006). The liver plays vital role to remove the toxicants from the body and the liver function can be altered by injury resulting from acute or chronic exposure to toxicants (Mahmoed and Rezq, 2013).

Fruits are beneficial for health due to phenolic substances components which possess antioxidant activity. Avocado is considered the world's healthiest fruit, because of its nutrient contents such as vitamin $\mathrm{K}$, dietary fiber, potassium, folic acid, vitamin $\mathrm{B} 6$, vitamin $\mathrm{C}$, copper and reasonable calories. It is one of the most recommended fruits as well as a food for body building and medicine for cholesterol-related diseases (Abdel-Moneim et al., 2017). Avocados fruit meet the definition of a functional food as outlined by the American Dietetic Association in that they provide health benefits beyond basic nutrition (Alghamdi and Yousef, 2017). Avocado fruits have protective effect against the loss of antioxidant activities as result of oxidative process caused by $\mathrm{CCl}_{4}$ injection due to its phytochemicals compounds (phenloic and flavonids) (Mahmoed and Rezq, 2013). 
Egyptian J. of Nutrition Vol. XXXV No. 1 (2020)

Kiwi fruit is one of the most popular fruits worldwide which has a high level vitamin $\mathrm{C}$ so it considered strong antioxidant. Kiwi contains high amount of ascorbic acid, carotenoids, lutein, and flavonoids so it has antioxidant properties (Shehata and Soltan, 2013). Kiwi extract showed protective effects and anti-oxidant effects as reported by Kang et al., (2012). Therefore, the present study aims to assess the protective effects of kiwi and avocado juices against indomethacin toxicity in experimental rats.

\section{Materials and methods}

\section{Plant materials and chemicals:}

The fresh avocado (Persea Americana Mill.) and kiwi fruit (Actinidia deliciosa) were purchased from the local market in kafr Elshekh, Egypt. Indo was obtained from the NILE Company of Pharmaceuticals and Chemical IND (in Egypt). Vitamins mixture and salt mixture and all chemicals used for blood biological measurements were purchased from El-Gomhorya Company for Chemical Industries, Cairo, Egypt.

\section{Preparation of juices:}

The mature fresh fruits (kiwi and avocado) were washed with tap water and peeled off and the flesh was homogenized using electric blender to get the juices and they were filtered through muslin cloth. The juices were prepared daily before use according to the method described by Al-Dosari (2011).

\section{Animals:}

Thirty-six male albino rats of Sprague Dawley strain $(185 \pm 10$ g) were obtained from the laboratory animal house of Faculty of Science, Tanta University. Rats were housed individually in wire 


\section{Amira L. Abd Allah}

cages, maintained for one week as acclimatization period under standard laboratory conditions. During acclimatization and the whole period of the experiment, rats were fed on basal diet. The diet had the following composition: corn oil 10\%, salt mixture (Hegsted et al., 1941) $4 \%$, vitamin mixture (Campbell, 1963) $1 \%$, choline chloride $0.2 \%$, protein $12 \%$ and corn starch up to $100 \mathrm{~g}$ (Reeves et al., 1993).

\section{Experimental Design:}

After the period of acclimatization, rats were divided into 6 groups each group contains 6 rats as follows:

Group (1): Negative control group (-ve).

Group (2): Positive control group (+ve) (treated with Indomethacin 25 $\mathrm{mg} / \mathrm{kg}$ only).

Group (3): Treated with kiwi juice (10 $\mathrm{ml} / \mathrm{Kg}$ Body weight /day orally) + Indomethacin $(25 \mathrm{mg} / \mathrm{kg})$.

Group (4): Treated with kiwi juice (20 ml/Kg Body weight/day orally) + Indomethacin (25 mg/kg).

Group (5): Treated with avocado juice (10 ml/Kg Body weight /day orally) + Indomethacin (25 mg/kg).

Group (6): Treated with avocado juice $(20 \mathrm{ml} / \mathrm{kg}$ Body weight/day orally) + Indomethacin ( $25 \mathrm{mg} / \mathrm{kg})$.

The doses of indomethacin and juices were selected from published literature according to Ajeigbe et al., (2014), andAl-Dosari, (2011). The fresh juices were given orally once daily for twenty-one days. The rats were fasted overnight before anesthetized and sacrificed after the examination period ( 21 days).

\section{Biological evaluation:}

Body weight gain and the quantities of diet which were consumed and leftover diet recorded every day during the experimental period (21days). The $\mathrm{FI}$ and BWG\% were calculated 
Egyptian J. of Nutrition Vol. XXXV No. 1 (2020)

according to (Chapman et al., 1959), and FER was calculated according to Hosoya, (1980).

\section{Biochemical evaluation and histopathological examination:}

The rats were fasted overnight before sacrificed after the examination period (21 days). The blood samples were collected after slight anesthesia of rats using diethyl ether from each rat and put immediately into glass tubes and centrifuged at 3,000 rpm for 20 min at $4{ }^{\circ} \mathrm{C}$ to obtain the serum which kept frozen at-20 ${ }^{\circ} \mathrm{C}$ for analysis as described by (Schermer, 1967). The livers were immediately removed from each rat, washed and cleaned from the adhesive matter by a saline solution $(0.9 \%, \mathrm{w} / \mathrm{v})$, dried by filter paper and kept in formalin solution (10\%) according to the method described by Drury and Wallington (1980) for histopathology examination.

\section{Hematological analysis:}

Different tested parameters in serum were determined using specific methods as follows: Liver enzymes (AST and ALT) were measured in the serum according to the method described by Reitman and Frankel (1957). Urea and creatinine were determined in the serum according to Patton and Crouch (1977)and Faulkner and King (1976). Red blood cell and white blood cells were determined based on the method was adopted by Fischbach, (1996). Hemoglobin ( $\mathrm{Hb})$ and hematocrit (HCT) levels were measured according to Drabkin, (1949) andMclnory, (1954), respectively.

\section{Statistical analysis:}

Data were expressed as means \pm standard deviation. Values were statistical analyzed by one-way analysis of variance (ANOVA test) using SPSS 10.1 software package. Differences were 


\section{Amira L. Abd Allah}

considered significant at $\mathrm{P}$ values (0.05) (Snedecor and Cochran, 1989).

\section{Results}

\section{Biological evaluation:}

Administration of indomethacin showed a significant decrease $(p<0.05)$ in $\mathrm{FI}, \mathrm{BWG} \%$ and FER when compared with normal (- ve) group. However, oral administrations of juices (kiwi juice or avocado juice) showed a significant increase $(P<0.05)$ in $F I$, BWG\%. On the other hand, insignificant differences were noticed between groups treated with fruit juices for increasing FER as compared to (+ve) group as shown in table (1).

\section{Liver function:}

It is clear from table results (2) that there were significant increases for ALT and AST levels in the serum of (+ve) group (59.02 \pm 5.21 and $276.09 \pm 15.63 \mathrm{lU} / \mathrm{L}$, respectively) as compared to negative control group $(21.02 \pm 2.94$ and98.40 $\pm 8.74 \mathrm{IU} / \mathrm{L}$, respectively). Results denote that all treated groups had significant decrease in serum levels of ALT and AST activities when compared with indomethacin treated group only. Treated group with high dose of avocado juice and kiwi juice $(20 \mathrm{ml} / \mathrm{kg})$ showed the highest decrease of ALT and AST enzyme levels in serum.

\section{Kidney function:}

Indomethacin caused a significant increase in kidney function, but oral administrations of juices (kiwi and avocado) recorded a significant decrease in kidney function (urea and creatinine) when compared with indomethacin treated group only. The mean values of urea and creatinine in control (+ve) group (73.22 \pm 9.38 and $1.14 \pm$ 
Egyptian J. of Nutrition Vol. XXXV No. 1 (2020)

$0.13 \mathrm{mg} / \mathrm{dL}$, respectively) was significant increase as compared to control (-ve) group was (21.54 \pm 3.44 and $0.53 \pm 0.06 \mathrm{mg} / \mathrm{dL}$, respectively). The best results were obtained with high dose $(20 \mathrm{ml} / \mathrm{kg})$ of kiwi juice followed by high dose of avocado juice.

\section{Hematological parameters (HCT\%, Hb, RBC and WBC):}

Administration of indomethacin showed a significant decline $(\mathrm{p}<0.05)$ in $\mathrm{RBC}, \mathrm{HCT} \%$ and $\mathrm{Hb}$ concentration. While, WBC were increased in indomethacin (+ve group) when compared with normal (ve group) group. However, these parameters improved in all treated groups with juices. The highest improvement observed in treated group with avocado juice at dose $(20 \mathrm{ml} / \mathrm{kg})$ and closed to normal group (Table 4).

\section{Histological results:}

Microscopic examination of $\mathrm{H} \& \mathrm{E}$ stained liver sections revealed normal histological pictures in control group. Similar histopathological lesions were observed in other experimental animals but they varied in severity among the treated groups (Table 5). In summary, microscopic examination of liver sections in the treated groups showed hepatocytes coagulative necrosis, microvesicular steatosis and ballooning degeneration, sinusoidal dilation besides expansion of portal areas due to congested portal blood vessels, biliary hyperplasia, portal fibrosis, portal inflammation.

\section{Discussion}

In the present study, administration of indomethacin showed a significant decrease in FI, BWG\% and FER because it interfere metabolic pattern of experimental rats and caused poor gastro intestinal functions with less absorption of nutrients according to 


\section{Amira L. Abd Allah}

Bagoji et al., (2015). These results agree with Fjære et al., (2014) who reported that indomethacin reduces feed efficiency and obesity in mice which treated with high fat/high sucrose and indomethacin due to reduced energy intake, feed intake was monitored. The positive improvement in theses parameters may be related to the active compounds which influence the gastrointestinal ecosystem, increasing production of digestive enzymes and improving digestion system according to Al-Mashhadani et al., (2013). On the other hand, the reduction in BWG\% of avocado juices may be due to high phenolic content in addition to its content of polyunsaturated fatty acids, which was reported to be present in avocado. This is in line with previous findings by Naveh et al., (2013) who reported that avocado consumption is associated with improved $\mathrm{FI}$ and lower BWG. Also, Alghamdi and Yousef (2017) concluded that the avocado it seems that avocado at $15 \%$ and $25 \%$ exert a protective effect against overweight.

Non-steroidal anti-inflammatory drugs are widely used worldwide (Scheiman et al., 2006) because they exert excellent efficacy in the management of pain, fever and inflammation (Simone, 2006) use of NSAIDs were accompanied with serious adverse effects not only in gastric but in the small intestine, cardiovascular system and liver (Filaretova et al., 2011 and Taiwo and Conteh 2008).

The liver has central role in detoxification of drugs and toxic substances, that make it is the target organ for all toxic effects (Mahmoed and Rezq, 2013). In this work, INDO-induced hepatotoxicity is evidenced by significant increase in the levels of serum AST and ALT. On another hand, treatment with juices of kiwi and avocado abated the hepatic lesions produced by indomethacin as evidenced by the reduction of the elevated serum levels of AST 
Egyptian J. of Nutrition Vol. XXXV No. 1 (2020)

and ALT. In the present study, the groups treated with high dose of avocado juice or kiwi juice showed the highest decrease in the serum level of AST and ALT. This is in line with previous findings by (Kang et al., 2012)who illustrated that treatment with kiwi fruit extract (KFE) effectively protected mice against $\mathrm{CCl}_{4}$-induced hepatotoxicity, as evidenced by reduced in levels of ALT and AST as compared to (+ve) group. Kiwi fruit contains great amounts of healthy dietary fiber and a variety of antioxidants. As a result, it can effectively prevent and treat liver disease (Iwasawa et al., 2010).The amelioration effects of KFE on hepatic toxicity of indomethacin may be attributed to the combination of several different mechanisms included: antioxidant activity; anti- inflammatory properties, and direct scavenge of free radicals with reduction oxidative stress and lipid peroxidation (Bekhradnia et al., 2011 and Sadek et al., 2012).

It also inhibited lipid peroxidation by metal chelating activity (Chou et al., 2008). Micronutrients such as vitamins $C$ and $E$, as well as carotenoid and phenolic compounds of kiwi fruit are strong antioxidants which play vital role against free radical (Fiorentino et al., 2009). The mechanism of kiwi extract for protection from hepatotoxicity could be the increased of anti-oxidative enzymes level and prevention of oxidation (Kang et al., 2012). Also, avocado fruits keep liver enzymes in normal levels that due to maintain antioxidant mechanisms (Mahmoed and Rezq, 2013). Flavonoids, rutin, catechin and quercetin are in nature widely and may act as strong antioxidants According to Terpinc et al., (2012).

Liver and kidney have primary role in drug metabolism and remove toxic substances that make these organs exposure to toxicity (Abd El-Megid et al., 2017). Where, the kidney functions also affected significantly by indomethacin administration as evidenced by 


\section{Amira L. Abd Allah}

the significant increase in renal function marker levels such as serum urea and creatinine in indomethacin treated rats as compared to the normal control. Where, these toxic effects were associated with the inhibition of prostaglandin synthesis and drug-elevated oxidative stress. Since the oxidative stress play a role in indomethacin-induced renal injury, alternative therapies including natural antioxidant agents (Koc et al., 2019), such as avocado juice and kiwi juice can be used to prevent the effects of oxidative stress produced. Where, Juices of kiwi and avocado effectively improved kidney functions and protected against damage induced by INDO due to its phytochemicals compounds (phenolics and flavonoids) which play vital role against free radical (Fiorentino et al., 2009)and(Mahmoed and Rezq, 2013).

Changes in hematological parameters showed the decrease in $\mathrm{Hb}$ and $\mathrm{HCT}$ concentration, RBCs count while increase in WBC count, that resulted from INDO caused deficiency in all types of blood cell. Our results agree with Bagoji et al., (2015) who reported that INDO caused decline RBC, HCT and $\mathrm{Hb}$ parameters in positive control group when compared to normal group. Also, Lateef and Taiwo (2006) who showed that INDO caused significant increase in WBC count. On the other hand, oral administration of avocado and kiwi juices increased RBC count and $\mathrm{Hb}$, HCT concentration while decreased the WBC count. This may be due to the high content of vitamin $E$ in avocado while Kiwi contain vitamin $C$ which acts as antioxidant .Our findings in line with Ibitoroko et al., (2011) showed that feeding on anti-oxidants vitamins $\mathrm{C}$ and $\mathrm{E}$ or combination of the two vitamins help to reversed the haematoxic damage by increasing the hemoglobin and reducing the white cell count. Also, Leontowicz et al., (2013) indicated that the RBC and HB in groups treated with 
Egyptian J. of Nutrition Vol. XXXV No. 1 (2020)

kiwi recorded levels higher than positive control group that the kiwi influences the RBC system in blood.

Moreover, these results are confirmed by histopathological examination as liver sections in indomethacin (+ve control) group showed severe diffuse necrotic lesions. These results agree with Bagoji et al., (2015) demonstrated that INDO damage the liver caused necrosis hepatocyte and relies the number of Kupffer cells. The fruit juices have protective effect against oxidative stress caused by indomethacin which improved some extent the histopathological picture. These results are supported by Mahmoed and Rezq (2013)demonstrated that sections of treated rats with $15 \%$ of avocado were normal hepatocytes due to phenolic compounds of avocado. Also, Amer et al., (2014)reported that pretreated of kiwi fruit extract revealed normal appearance of hepatocyte, central vein and sinusoid, the kiwi fruit has hepatic protective against toxicity of indomethacin that due to antioxidant activity and inflammatory properties of kiwi fruit.

\section{Conclusion}

Indomethacin has toxic side effects on human body that proved by biochemical and histological results. The results concluded that using high doses of kiwi and avocado juices improved liver and kidney function and hematological parameters. According to the results, tested juices could be used for protection from hepatotoxicity and nephrotoxicity caused by indomethacin. 
Amira L. Abd Allah

Table (1): Effect of kiwi and avocado juices on FI, BWG\% and FER in rats infected with toxicity indomethacin

\begin{tabular}{l|c|c|c}
\hline Groups & FI g/day & BWG\% & FER \\
\hline$(-v e)$ & $25.55^{\mathrm{a}} \pm 2.102$ & $17.78^{\mathrm{a}} \pm 1.890$ & $0.062^{\mathrm{a}} \pm 0.006$ \\
\hline$(+\mathrm{ve})$ & $7.33^{\mathrm{c}} \pm 0.575$ & $4.39^{\mathrm{d}} \pm 0.282$ & $0.051^{\mathrm{b}} \pm 0.004$ \\
\hline $10 \mathrm{ml} / \mathrm{Kg}$ Kiwi juice & $9.19^{\mathrm{c}} \pm 1.259$ & $10.81^{\mathrm{b}} \pm 1.090$ & $0.055^{\mathrm{b}} \pm 0.003$ \\
\hline $20 \mathrm{ml} / \mathrm{Kg}$ Kiwi juice & $17.03^{\mathrm{b}} \pm 0.991$ & $10.54^{\mathrm{b}} \pm 1.314$ & $0.052^{\mathrm{b}} \pm 0.006$ \\
\hline $10 \mathrm{ml} / \mathrm{kg}$ Avocado juice & $15.42^{\mathrm{b}} \pm 1.900$ & $8.06^{\mathrm{c}} \pm 0.670$ & $0.049^{\mathrm{b}} \pm 0.012$ \\
\hline $20 \mathrm{ml} / \mathrm{kg}$ Avocado juice & $17.25^{\mathrm{b}} \pm 2.250$ & $7.34^{\mathrm{c}} \pm 0.429$ & $0.035^{\mathrm{c}} \pm 0.008$ \\
\hline
\end{tabular}

All results are expressed as mean $\pm S$. D.

Values in each column, which have different letters are significant different $(p<0.05)$.

Table (2): Effect of kiwi and avocado juices on liver enzymes in rats infected with toxicity indomethacin

\begin{tabular}{l|c|c}
\hline Groups & ALT (IU/L) & AST (IU/L) \\
\hline$(-v e)$ & $21.02^{\mathrm{d}} \pm 2.94$ & $98.40^{\mathrm{e}} \pm 8.74$ \\
\hline$(+\mathrm{ve})$ & $59.02^{\mathrm{a}} \pm 5.12$ & $276.09^{\mathrm{a}} \pm 15.63$ \\
\hline $10 \mathrm{ml} / \mathrm{Kg}$ Kiwi juice & $51.53^{\mathrm{ab}} \pm 5.73$ & $249.05^{\mathrm{b}} \pm 13.12$ \\
\hline $20 \mathrm{ml} / \mathrm{Kg}$ Kiwi juice & $35.93^{\mathrm{c}} \pm 3.49$ & $168.50^{\mathrm{d}} \pm 17.87$ \\
\hline $10 \mathrm{ml} / \mathrm{kg}$ Avocado juice & $44.10^{\mathrm{b}} \pm 5.66$ & $210.55^{\mathrm{c}} \pm 16.09$ \\
\hline $20 \mathrm{ml} / \mathrm{kg}$ Avocado juice & $32.00^{\mathrm{c}} \pm 2.84$ & $154.57^{\mathrm{d}} \pm 9.02$ \\
\hline
\end{tabular}

All results are expressed as mean $\pm \mathrm{S}$. D.

Values in each column, which have different letters are significant different $(p<0.05)$. 
Egyptian J. of Nutrition Vol. XXXV No. 1 (2020)

Table (3): Effect of kiwi and avocado juices on some kidney function in rats infected with toxicity indomethacin

\begin{tabular}{c|c|c}
\hline Groups & Urea $(\mathrm{mg} / \mathrm{dL})$ & Creat. $(\mathrm{mg} / \mathrm{dL})$ \\
\hline$(-v e)$ & $21.54^{\mathrm{c}} \pm 3.44$ & $0.53^{\mathrm{d}} \pm 0.06$ \\
\hline$(+v e)$ & $73.22^{\mathrm{a}} \pm 9.38$ & $1.14^{\mathrm{a}} \pm 0.13$ \\
\hline $10 \mathrm{ml} / \mathrm{Kg} \mathrm{Kiwi}$ juice & $48.30^{\mathrm{b}} \pm 8.63$ & $0.86^{\mathrm{b}} \pm 0.04$ \\
\hline $20 \mathrm{ml} / \mathrm{Kg}$ Kiwi juice & $24.40^{\mathrm{c}} \pm 3.57$ & $0.54^{\mathrm{d}} \pm 0.050$ \\
\hline $10 \mathrm{ml} / \mathrm{kg}$ Avocado juice & $63.37^{\mathrm{a}} \pm 9.90$ & $0.95^{\mathrm{b}} \pm 0.08$ \\
\hline $20 \mathrm{ml} / \mathrm{kg}$ Avocado juice & $37.97^{\mathrm{b}} \pm 2.20$ & $0.69^{\mathrm{c}} \pm 0.06$ \\
\hline
\end{tabular}

All results are expressed as mean $\pm \mathrm{S}$. D.

Values in each column, which have different letters are significant different $(p<0.05)$.

Table (4): Effect of kiwi and avocado juices on hematological parameters in rats infected with toxicity indomethacin

\begin{tabular}{l|c|c|c|c}
\hline Groups & $\begin{array}{c}\text { RBC } \\
\left(10^{6} \mathrm{cell} / \mu \mathrm{L}\right)\end{array}$ & $\begin{array}{c}\text { WBC } \\
\left(\times 10^{3}\right)\end{array}$ & $\begin{array}{c}\mathrm{Hb} \\
(\mathrm{g} / \mathrm{dL})\end{array}$ & HCT\% \\
\hline$(-\mathrm{ve})$ & $9.36 \pm 0.17^{\mathrm{a}}$ & $8.47 \pm 0.45^{\mathrm{e}}$ & $14.03 \pm 0.55^{\mathrm{b}}$ & $43.40 \pm 2.42^{\mathrm{a}}$ \\
\hline$(+\mathrm{ve})$ & $5.51 \pm 0.46^{\mathrm{d}}$ & $21.00 \pm 1.00^{\mathrm{a}}$ & $11.63 \pm 0.15^{\mathrm{c}}$ & $32.13 \pm 1.86^{\mathrm{b}}$ \\
\hline $\begin{array}{l}10 \mathrm{ml} / \mathrm{Kg} \mathrm{Kiwi} \\
\text { juice }\end{array}$ & $7.67 \pm 0.15^{\mathrm{c}}$ & $19.40 \pm 1.15^{\mathrm{ab}}$ & $14.77 \pm 1.46^{\mathrm{ab}}$ & $41.63 \pm 4.48^{\mathrm{a}}$ \\
\hline $\begin{array}{l}20 \mathrm{ml} / \mathrm{Kg} \mathrm{Kiwi} \\
\text { juice }\end{array}$ & $8.23 \pm 0.31^{\mathrm{b}}$ & $18.10 \pm 0.10^{\mathrm{bc}}$ & $15.00 \pm 1.05^{\mathrm{ab}}$ & $43.83 \pm 1.76^{\mathrm{a}}$ \\
\hline $\begin{array}{l}10 \mathrm{ml} / \mathrm{kg} \\
\text { Avocado juice }\end{array}$ & $8.29 \pm 0.34^{\mathrm{b}}$ & $16.77 \pm 1.91^{\mathrm{c}}$ & $15.53 \pm 0.25^{\mathrm{ab}}$ & $42.47 \pm 1.33^{\mathrm{a}}$ \\
\hline $\begin{array}{l}20 \mathrm{ml} / \mathrm{kg} \\
\text { Avocado juice }\end{array}$ & $8.32 \pm 0.24^{\mathrm{b}}$ & $13.73 \pm 0.87^{\mathrm{d}}$ & $15.67 \pm 0.32^{\mathrm{a}}$ & $44.97 \pm 0.73^{\mathrm{a}}$ \\
\hline
\end{tabular}

All results are expressed as mean $\pm S$. D.

Values in each column, which have different letters are significant different $(p<0.05)$. 


\section{Amira L. Abd Allah}

Table (5): Scoring of histological lesions in liver in all the experimental groups

\begin{tabular}{|c|c|c|c|c|c|c|}
\hline Liver & -ve & +ve & $10 \mathrm{ml} / \mathrm{kg} \mathrm{KJ} *$ & $20 \mathrm{ml} / \mathrm{kg} \mathrm{KJ}$ & $10 \mathrm{ml} / \mathrm{kg} \mathrm{AJ} *$ & $20 \mathrm{ml} / \mathrm{kg} \mathrm{AJ}$ \\
\hline Portal congestion & - & +++ & + & + & + & \pm \\
\hline Sinusoidal dilation & - & +++ & + & + & ++ & + \\
\hline Portal fibrosis & - & ++ & + & \pm & \pm & \pm \\
\hline Biliary hyperplasia & - & ++ & ++ & + & ++ & + \\
\hline Portal inflammation & - & ++ & + & - & + & - \\
\hline $\begin{array}{l}\text { Hepatocytes } \\
\text { coagulative necrosis }\end{array}$ & - & +++ & ++ & + & + & \pm \\
\hline $\begin{array}{l}\text { Microvesicular } \\
\text { steatosis or } \\
\text { ballooning } \\
\text { degeneration in } \\
\text { hepatocytes }\end{array}$ & - & +++ & + & - & + & - \\
\hline
\end{tabular}

* KJ: Kiwi juice

*AJ: Avocado juice

*The results obtainedfrom histological liver sections illustrated in Fig.1. Liver sections, shows no lesions scored -in Normal (-ve) group (A). However, liver sections from indomethacin (+ve) group showed severe diffuse necrotic lesions scored +++ (B), moderate diffuse necrotic lesions scored ++ in kiwi juice group (low dose) (C). when compared to mild necrotic lesions scored \pm in kiwi juice group (high dose) (D), moderate multifocal necrotic lesions scored + in avocado juice group (low dose) (E) when compared to mild necrotic lesions scored \pm in avocado juice group (high dose) (F).X: 100 bar 100.

*Severe lesions (red colored arrows), moderate diffuse lesions (black colored arrows), moderate multifocal lesions (blue colored arrows), mild lesions (yellow colored arrows). 
Egyptian J. of Nutrition Vol. XXXV No. 1 (2020) 


\section{Amira L. Abd Allah}

\section{References}

Abatan, M. O.; Lateef, I. and Taiwo, V.O. (2006):

Toxic effects of non-steroidal anti-inflammatory agents in rats. African Journal of Biomedical Research. 9, 219-223.

Abd El-Megid, M.H.M.; Abdul Azeem, A. M. and El-Shahat, A.N.; Mekawey, H. M. S. (2017):

Identification of the therapeutic effects of gammairradiated chamomile aqueous extract against alcohol induced hepatonephrotoxicity in rats. Egypt. J. Rad. Sci. Applic. 30: 53 - 61.

Abdel-Moneim, A. A.; Ahmed, O.M.; Fahim, H.I. and Mohamed, E.E. (2017):

The Preventive Effects of Avocado Fruit and Seed Extracts on Cardio-nephrotoxicity Induced by Diethyl nitrosamine/ 2-acetyl aminoflurine in Wistar Rats. Basic Sciences of Medicine. 6, 413.

Ajeigbe, K.O.; Onifade, A. A.; Omotoso, D.R.; Enitan, S.S. and Olaleye, S.B. (2014):

Anti-ulcerogenic activity of aspiliaafricana leaf extract: Roles of gastric acid, oxidative stress and neutrophil infiltration. Afr. J. Biomed. Res., 1, 193-201.

Al-Dosari, M. S.(2011):

Hypolipidemic and antioxidant activities of avocado fruit pulp on high cholesterol fed diet in rats. Afr. J. Pharm. Pharmacol., $5,1475-1483$. 
Egyptian J. of Nutrition Vol. XXXV No. 1 (2020)

Alghamdi, E. S. and Yousef, F. M. A. (2017):

Effect of Avocado on Serum Lipids of Hyperlipidemic Rats.

Curr. Sci. Int., 6, 199-207.

Al-Mashhadani, H.; Mashhadani, E. H. and Al-Shamire, J.S. (2013):

Effect of supplementing different levels of chamomile oil on broiler performance and some physiological traits. International Journal of Poultry Science. 12, 426-429.

Amer, M.A.; Eid, J.I. and Hamad, R. (2014):

Evaluation of Gastric and Hepatic Protective Effects of Kiwifruit Extract on Toxicity of Indomethacin in Swiss Albino Mice Using Histological Studies. International Journal of Science and Research (IJSR). 3, 1631-1641.

Andrade-Dávila, V.F.; Chávez-Tostado M.; Dávalos-Cobián C.et al., (2015):

Rectal indomethacin versus placebo to reduce the incidence of pancreatitis after endoscopic retrograde cholangiopancreatography: results of a controlled clinical trial. BMC Gastroenterol., 15(1):85.

Bagoji ,I. B.; Jargar, J. G.; Yendigeri ,S. M.; Doshi , M. A.; Patil, B. G. and Das, K. K.(2015):

Effect of supplementation of black tea extract on indomethacin induced alteration of pathophysiology of rat liver. Journal of Chemical and Pharmaceutical Research. 7, 597-604.

Bekhradnia, S.; Nabavi, S.M.; Nabavi, S.F. and Ebrahimzadeh, M.A. (2011):

antioxidant activity of kiwifruit (Actinidiachinensis). Pharmacology online 1, 758-764. 


\section{Amira L. Abd Allah}

Campbell, J.A. (1963):

Methodology of Protein Evaluation. RAG Nutr., Document R. 101 Ed., 37. June Meeting New York.

Chapman, D.G.; Castilla, R. and Cambell, A.J. (1959):

Evaluation of protein in food. In Method for the Documentation of protein Efficiency Ratio. Can. J. Biochem. Physiol., 37, 679686.

Chou, H. N.; Nee, C.C.; Ou, A. S. M.; Chou, T. H. and Chien, C. C. (2008):

Characterization of the physicochemical and antioxidant properties of Taiwanese kiwi fruit (Actinidiasetosa). Botanical Studies 49, 215-224.

Drabkin, D. (1949):

The standardization of hemoglobin measurements. Am. J. Med. Sci., 21, 71.

Drury, R.A. and Wallington, E.A.(1980):

Carleton's Histological Technique". 5th Ed., Oxford University, New York, Toronto.

Faulkner, N.R. and King, J.W.(1976):

Fundamental of Clinical Chemistry". 2nd Ed. Tietz Editor. Saunders Philadelphia, pp. 994-998.

Filaretova, L.P.; Bagaeva, T.R.; Morozova, O.Y. and Zelena, D.(2011):

The healing of NSAID induced gastric lesion may be followed by small intestinal and cardiovascular side effects. Journal of Physiology and Pharmacology.62, 619-625. 
Egyptian J. of Nutrition Vol. XXXV No. 1 (2020)

Fiorentino, A. B.; Abrosca, D.; Pacifico, S.; Mastellone, C.; Scognamiglio, M. and Monaco, P. (2009):

Identification and assessment of antioxidant capacity of phytochemicals from kiwi fruits. J. Agri. and Food Chem., 57, 4148-4155.

Fischbach, F.T. (1996):

A manual of Laboratory and Diagnostic Tests 5th Ed. Lippincott, Philadephia New York, pp. 31-120.

Fjære, E.; Aune, U. L.; Røen, K.; Keenan, A. H.; Ma, T.; Borkowski, K.; Kristensen, D.M.; Novotny, G. W.; Mandrup-Poulsen, T.; Hudson, B. D.; Milligan, G.; Xi, Y.; Newman, J.W.; Haj, F. G.; Liaset, B.; Kristiansena, K. and Madsen, L. (2014):

Indomethacin Treatment Prevents High Fat Diet-induced Obesity and Insulin Resistance but Not Glucose Intolerance in C57BL/6J Mice. The Journal of Biological Chemistry. 289, 16032-16045.

Hegsted, D. M.; Mills, R.C.; Elvehyen, C.A. and Hart, E.B. (1941):

Choline in the Maturation of Chicks. J. Biol. Chem., 138: 459.

Hosoya, N. (1980):

Determination of feed efficiency ratio. Cited in Hosoya, N.; Inami, S. and Goto, S., eds. Nutrition Experiments Using Small Animals. Daiichi Shuppan, Tokyo, Japanese, pp:71.

Ibitoroko, G.M.; Adebayo, A.O. and Confidence, W.K. (2011):

Effect of Vitamins $C$ and $E$ on Hematological Parameters in Albino Rats Treated with Gasoline. Global Veterinaria. 7, 347352. 


\section{Amira L. Abd Allah}

Iwasawa, H. E.; Morita, H. U. and Yamazaki, M. (2010):

Influence of Kiwi Fruit on Immunity and Its Anti-oxidant Effects in Mice. Food Sci. Technol. Res., 16, 135 -142.

Kang, W.; Yang, H.; Hong, H. J.; Han, C. H. and Lee, Y. J. (2012): Anti-oxidant activities of kiwi fruit extract on carbon tetrachloride-induced liver injury in mice. Korean J. Vet. Res., $52,270-280$.

Koc, K.; Cerig, S.; Ozek, N. S.; Aysin, F.; Yildirim, S. ; Cakmak, O.; Hosseinigouzdagani, M. and Geyikoglu, F. (2019):

The efficacy of oleuropein against non-steroidal antiinflammatory drug induced toxicity in rat kidney. Environmental Toxicology. 34:67-72.

Lateef, A.M. and Taiwo, V.O. (2006):

Toxic Effects of Non-Steroidal Anti-Inflammatory Agents in Rats. African Journal of Biomedical Research.9, 219 -223.

Leontowicz, M.;Jesion, I.; Leontowicz, H.; Park, Y.S.;Namiesnik, J.;Rombolà, A.D.;Weisz, M. andGorinstein , S. (2013): Health-promoting effects of ethylene-treated kiwifruit 'Hayward' from conventional and organic crops in rats fed an atherogenic diet. J. Agric. Food Chem., 17, 3661-3668.

Mahmoed, M. Y. and Rezq, A.A. (2013):

Hepatoprotective Effect of Avocado Fruits Against Carbon Tetrachloride-Induced Liver Damage in Male Rats. World Applied Sciences Journal. 21, 1445-1452. 
Egyptian J. of Nutrition Vol. XXXV No. 1 (2020)

McInory, L. (1954):

A micro heamatocrit for determining the packed cell and hemoglobin concentration on capillary blood. J. Clin. Path.,7, 32.

Naveh, E.; Werman, M.; Sabo E. and Neeman, I. (2013):

Defatted avocado pulp reduces body weight and total hepatic fat but increases plasma cholesterol in male rats fed diets with cholesterol. J. Nutrition.Org., 2015- 2018.

Patton, C. J. and Crouch, S.R. (1977):

Enzymatic colorimetric method for determination of urea in serum. Anal. Chem., 49, 464-469.

Perron, N.; Tremblay, E.; Ferretti, E. et al., (2013):

Deleterious effects of indomethacin in the mid-gestation human intestine. Genomics. 101(3):171-177.

Reeves, P.G.; Nielsen, F.H. and Fahmy, G.C. (1993):

Reported of the Amirican Institute of Nutrition adhoewriling committee on the reformulation of the AIN-76A- Rodendeit. J Nutr., 123:1939 -1951.

Reitman, S. and Frankel, S. (1957):

A colorimetric method for the determination of serum glutamic oxaloacetic and glutamic pyruvic transaminases". Am. J. Clin. Path. , 28, 56.

Sadek, M.; Aref, A. M. I.; Khalil, F. A.; Barakat, L. A. A.; Ali, N. H. and Soliman, B.S. M. (2012):

Impact of Actinidiadeliciosa (Kiwi fruit) consumption on oxidative stress status incarcinogenesis. African J. Biol. Sci., 8,117-127. 


\section{Amira L. Abd Allah}

Scheiman, J. M.; Yeomans, N. D.; Talley, N. J.; Vakil, N.; Chan, F. K.; Tulassay, Z.;Rainoldi, J. L.; Szczepanski, L.; Ung, K. A.; Kleczkowski, D.; Ahlbom, H.; Naesdal, J. and Hawkey, C. (2006):

Prevention of ulcers by esomeprazole in at-riskpatients using non-selective NSAIDs and COX-2 inhibitors. Am. J. Gastroenterol., 101,701-710.

Schermer, S. (1967):

The Blood Morphology of Laboratory Animals. Philadelphia: F. A. Davies Co., p. 359.

Shehata, M.M.S. and Soltan, S. S.A. (2013):

Effects of Bioactive Component of Kiwi Fruit and Avocado (Fruit and Seed) on Hypercholesterolemic Rats. World Journal of Dairy \& Food Sciences. 8, 82-93.

Simone, R. (2006):

Australian Medicines Handbook. Adelaide: Australian Medicines Handbook Pty Ltd, ISBN 0-9757919-2-3.

Snedecor, G. W. and Cochran, W. G.(1989):

Statistical Methods. Eighth Edition, lowa State University Press.

Taiwo, V.O. and Conteh, O.L. (2008):

The rodenticidal effect of indomethacin: pathogenesis and pathology.VeterinarskiArhiv. 78,167-178.

Terpinc, P.; Polak, T.; Makuc, D.; Ulrih, N.P. and Abramovic, H. (2012):

The occurrence and characterization of phenolic compounds in Camelina sativa seed, cake and oil. Food Chem., 131, 580-589. 
Egyptian J. of Nutrition Vol. XXXV No. 1 (2020)

$$
\text { التأثيرات الوقائية لبعض العصائر على سمية الإندوميثاسين في }
$$

\section{أميرة لطفي عبد الرؤف عبد الله}

قسم التغذية وعلوم الأطعمة. كلية الاقتصاد المنزلي- جامعة الأزهر

$$
\text { الملخص العربى }
$$

أجريت هذه الدراسة للتعرف على فعالية العصائر الطازجة (الكيوي والأفوكادو) ضد الإندا

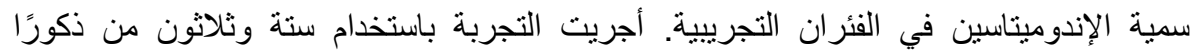

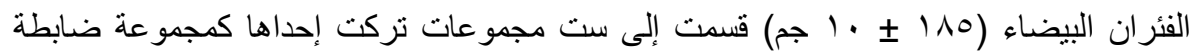

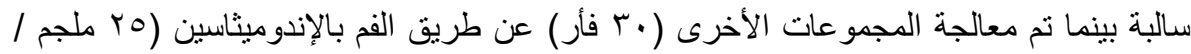

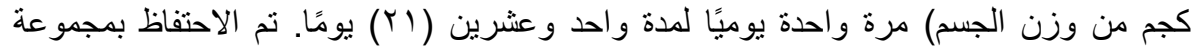

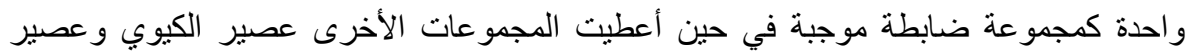

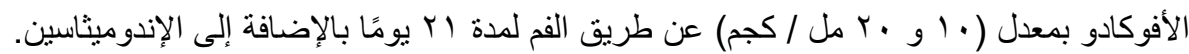

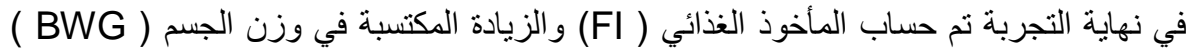

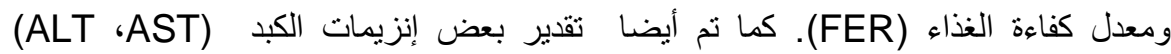

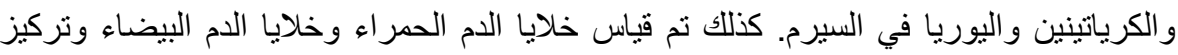

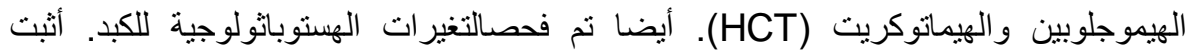

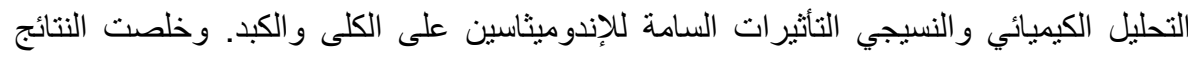

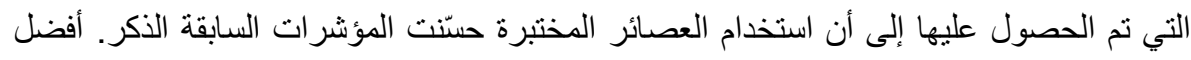

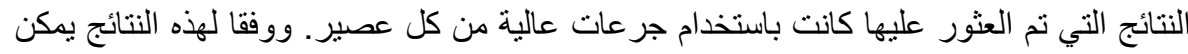
استخدام العصائر المختبرة للحماية من السمية الناتجة عن الإندوميتاسين. 